Transformation of the French Pattern of a Naturalistic Character in Ivan Franko's Literary Works

Author(s): Nataliia Yatskiv, Nataliia Venhrynovych

Source: Kyiv-Mohyla Humanities Journal 5 (2018): 183-200

Published by: National University of Kyiv-Mohyla Academy

http://kmhj.ukma.edu.ua/ 


\title{
Transformation of the French Pattern of a Naturalistic Character in Ivan Franko's Literary Works
}

\author{
Nataliia Yatskiv \\ Vasyl Stefanyk Precarpathian National University, \\ French Philology Department \\ Nataliia Venhrynovych \\ Ivano-Frankivsk National Medical University, \\ Linguistics Department
}

\begin{abstract}
The article deals with the means of constructing a naturalistic character, the model for which was proposed by French writers: the Goncourt brothers and Émile Zola. Naturalists draw their personage concept from the interpretation of its biological nature. The focus of its depiction is shifted to the study of fundamental features of human nature rather than "variables" of the historical forms of its manifestation. A naturalistic character, being "a biological being" rather than "a set of social relations," is completely absorbed by the environment. The "social" core of a realistic personage is based on the principles of typification, but the "biological" core of a naturalistic character cannot be a generalized type because in it the individual prevails over the typified. Images of Germinie Lacerteux and Thérèse Raquin from the Goncourts' and Zola's same-name novels respectively are considered to be prototypes of naturalistic characters. In Ukrainian literature, Ivan Franko interpreted and synthesized Western European experience using realistic and naturalistic art to create his own concept of "scientific realism." The difference in Franko's personage construction lies in the fact that he does not confine himself to the observation and description of his heroes' behavior but offers a plan for correcting their deficiencies.
\end{abstract}

Key Words: naturalism, realism, Ivan Franko, artistic image, physiological determinism, temperament.

The phenomenon of naturalism belongs to epoch-making phenomena that evoke constant discussion, thereby attracting attention to the problem of the relationship between art and life as well as to the revaluation of ontological values. Recent investigations in Ukrainian literary criticism draw the problem of naturalism into the plane of the theoretical generalization of the genetic-typological paradigm of the international invariant of a literary movement, thus constructing a model of a common denominator based on the philosophical and aesthetic works of Émile Zola, offering 
a certain set of fundamental principles and constitutive dominants, whose presence or absence enables the identification of a particular phenomenon of the literary process as one related to naturalism. Roman Holod's, ${ }^{1}$ Volodymyr Matviishyn's, ${ }^{2}$ and Dmytro Nalyvaiko's ${ }^{3}$ works are focused on the study of naturalism's genetic-typological nature as an independent unit of the literary process and its harmonious unity of ideological, philosophical, and poetical elements that make it possible to delineate the above mentioned phenomenon into a literary movement, whose constitutive dominants are scientism, objectivity, a monistic worldview, and the principle of life resemblance. ${ }^{4}$ These critical works trace the evolution of naturalism through contact-genetic relationships with its fundamental doctrine, formulated by Zola in his Le Roman expérimental, and analyze typological coincidences and differences in the transformation of the movement in various national literatures.

Despite the overall unanimity of theoreticians concerning the philosophical foundation of the movement (positivist philosophy), its mimetic aesthetics, the veracious depiction of life and scientism, which demonstrate the genetic relationship of naturalism and realism, the system of poetic means, and in particular, the concept of a personage in a naturalistic artistic work, requires further investigation. Therefore, the purpose of our paper is to study the array of means of depiction with the help of which the main character of a naturalistic novel is outlined and is made either similar to a realistic character or different from it. Taking into account the fact that the fundamental principles of naturalism are set forth in French literature, we will try to trace the relations between naturalistic characters in the Goncourt brothers' and Zola's novels and the personages of the representatives of Ukrainian naturalism, and in particular, to determine the typological similarities and differences of protagonists in the literary works of Ivan Franko, owing to whom the French phenomenon has become an important factor in the rejuvenation of Ukrainian national literature.

Émile Zola is the founder and best-known practitioner of the literary school of naturalism. His novel Thérèse Raquin (1867) can be considered the literary prologue that caused much discussion about a new method for the presentation of reality. In his preface to the second edition, responding to his contemporaries' acute criticism and accusations of "stink and putridity" that his novel echoes, the author substantiates his task as one "to study temperament, not character ... to perform on two living bodies

1 Roman Holod, Ivan Franko ta literaturni napriamy kintsia XIX_pochatku XX stolittia [Ivan Franko and Literary Movements of the Late 1gth -Early 2oth Centuries] (Ivano-Frankivsk: Lileia-NV, 2005).

2 Volodymyr Matviishyn, "Poetyka frantsuzkoho naturalizmu u svitli literaturno-krytychnykh zasad Ivana Franka [French Naturalist Poetics in the Light of Ivan Franko's Literary and Critical Foundations]," in Literatura. Chas. Postati, ed. Nataliia Venhrynovych (Ivano-Frankivsk: Vasyl Stefanyk Precarpathian National University, 2013), 229-36. Dmytro Nalyvaiko, Iskusstvo: napravleniia, techeniia, stili [Art: Movements, Trends, Styles] (Kyiv: Mystetstvo, 1985). 
the analytical work that surgeons carry out on corpses." 5 In creating his characters Zola followed his scholarly purpose and "tried to explain the strange union that can take place between two different temperaments, showing the profound disturbances of a sanguine nature when it comes into contact with a nervous one." ${ }^{6}$ Influenced by her passion for Laurent, which reaches its apogee at the moment of voyeuring at her husband's murder, Thérèse Raquin becomes a nervous, mentally unbalanced person seeking pleasure in instant exaltations, reading dime novels, God worshiping, drunkenness, and violence, finally calming herself in suicide.

In fairness, it should be noted that Zola was not the first writer to speak of naturalism. A similar metamorphosis, that is, temperament change under the influence of the environment, namely, the experience of a crisis culmination, was previously used by the Goncourt brothers in their novel Germinie Lacerteux (1865). This work gave rise to a controversy between long-time friends for the right to champion the modernization of the genre of the novel and afforded grounds for the Goncourts to accuse Zola of plagiarism. The problem is easily solved, as the Goncourt brothers had the habit of supplementing all their works with prefaces, therefore it is not difficult to notice similarities in the proclamation of program tasks:

Today, as the novel expands and deepens, it begins to be a serious, passionate, living form of literary study and social inquiry, through analysis and psychological research it turns into contemporary moral history; now that the novel solves the same tasks and assumes the same commitments as science does, it can claim its liberties and franchises... It's high time to check whether, in a word, the tears shed by the lower class of society can cause the same sympathy as the tears shed by the upper one. ${ }^{7}$

5 Émile Zola, Thérèse Raquin (La Bibliothèque électronique du Québec, Collection À tous les vents), 6, https://beq.ebooksgratuits.com/vents/zola-raquin.pdf. (J'ai simplement fait sur deux corps vivants le travail analytique que les chirurgiens font sur des cadavres.) Here and subsequently, unless otherwise indicated, translations from French are by Nataliia Yatskiv and Nataliia Venhrynovych.

6 Zola, Thérèse Raquin, 6. (J'ai cherché à suivre pas à pas dans ces brutes le travail sourd des passions, les poussées de linstinct, les détraquements cérébraux survenus à la suite d'une crise nerveuse.)

7 Edmond et Jules de Goncourt, Germinie Lacerteux (La Bibliothèque électronique du Québec, Collection À tous les vents), 7, accessed May 4, 2017, https://beq.ebooksgratuits.com/vents/ Goncourt-Germinie.pdf. (Aujourd'hui que le Roman s'élargit et grandit, qu'il commence à être la forme sérieuse, passionnée, vivante, de l'étude littéraire et de l'enquête sociale, qu'il devient, par l'analyse et par la recherche psychologique, l'Histoire morale contemporaine; aujourd'hui que le Roman s'est imposé les études et les devoirs de la science, il peut en revendiquer les libertés et les franchises... Il nous est venu la curiosité de savoir ... si, en un mot, les larmes qu'on pleure en bas pourraient faire pleurer comme celles qu'on pleure en haut.) 
We can compare the Goncourts' words with those of Zola in his novel L'Assommoir: "It is a work of truth, the first novel about the people that does not lie and which has the true smell of the people" (1877). ${ }^{8}$ Thus, 1865 may rightfully be considered the starting point of the naturalistic movement.

Unlike the Goncourt brothers, who in each novel sought to reveal a new view of reality based on their own observations, carefully recorded in their Journal des Goncourt for later use in fiction works, Zola developed his theory of naturalism and created a series of critical articles, substantiating the new method of presenting reality relying on positivist philosophy, Bernard's experimental medicine, as well as the work of his forerunners: Honoré de Balzac, Gustave Flaubert, and above all the Goncourt brothers. In the context of the problem under study, Zola emphasized the importance of causal relationships while depicting the personages' characters, thus keeping with the realists. Nevertheless, the naturalists' absolutization of determinism leads to denial of the accidental and indeterministic while elucidating the causes of a phenomenon or a character's behavior. The author of Le Roman expérimental adopts C. Bernard's thesis on "the triumph of reason," which consists of conquering evermore new areas for determinism with the help of an experimental method, and expresses his faith in determinism, which "governs the stones of the roadway and the brain of man." ${ }^{9}$ Taking into account and referring to Darwin's theory on "race" study, Zola in this context theoretically substantiates the importance of heredity, which, as it later becomes clear, will become the "cornerstone" in the naturalistic concept of a personage, "Without daring ... to formulate laws, I consider that the question of heredity has a great influence in the intellectual and passionate manifestations of man." ${ }^{10}$ Equally ambiguously, Zola declares that a writer must carefully study the environment in which the formation of personages' characters takes place, because "in the study of a family, of a group of living beings, ... the social condition is of great importance." ${ }^{11}$ Moreover, since a person lives in society, the writer's main task is to study "the reciprocal effect of society on the individual and the individual on society." ${ }^{12}$

8 Émile Zola, Les Rougon-Macquart. L’Assommoir (La Bibliothèque électronique du Québec, Collection À tous les vents), 6, accessed May 4, 2017, https://beq.ebooksgratuits.com/ventsxpdf/Zola-o7.pdf. (C'est une oeuvre de vérité, le premier roman sur le peuple, qui ne mente pas et qui ait l'odeur du peuple.)

Émile Zola, Le Roman expérimental (Paris: G. Charpentier éditeur, 1881), 15. (... un même déterminisme doit régir la pierre des chemins et le cerveau de l'homme.) Translated by Belle M. Sherman.

Zola, Le Roman expérimental, 18. (Sans me risquer à formuler les lois, j'estime que la question d'hérédité a une grande influence dans les manifestations intellectuelles et passionnelles d'homme.) Translated by Belle M. Sherman.

11 Zola, Le Roman expérimental, 19. (... dans l'étude d'une famille, d'un groupe d'êtres vivants, je crois que le milieu social a également une importance capitale.) Translated by Belle M. Sherman.

12 Zola, Le Roman expérimental, 19. (... notre grande étude est là, dans le travail réciproque de la société sur l'individu et de l'individu sur la société.) Translated by Belle M. Sherman. 
Consequently, both realists and naturalists agree that the fate and behavior of a person is determined by socio-historical circumstances, but the realists' artistic historicism of determinism focuses on a combination of typical characters and circumstances, including, besides social factors, psychological and natural ones. ${ }^{13}$ But a naturalism theoretician interprets the peculiarities of human nature as an object rather than a subject of cognitive activity:

When it has been proved that the body of man is a machine, whose machinery can be taken apart and put together again at the will of the experimenter, we can then pass to the passionate and intellectual acts of man. ${ }^{14}$

In accordance with this approach, man is regarded as a soulless mechanism, completely deprived of either individual freedom or the right to any internal immanent irrational motivation. Analyzing the difference between realism and naturalism, D. Nalyvaiko remarks that it is the "physiology" in the interpretation of the environment and man that leads to the gap between naturalistic and realistic tradition. "In a naturalistic sense of the environment, the tendency towards intimacy with "nature" and, consequently, a greater departure from "history" is becoming increasingly apparent." 15 The weakening of historicism develops into anti-historicism. Since the naturalists' concept of a personage proceeds from the interpretation of its biological nature, which is dependent on physiological laws, the focus of their presentation is shifted to the study of the fundamental features of human nature rather than to "variables" of the historical forms of its manifestation. Being "a biological being" rather than "a set of social relations," a naturalistic character is completely absorbed by the environment and is submitted to its rules and laws. A personage's empirical character and authenticity are interpreted by the literary critic as the main discrepancy in the structure of realistic and naturalistic artistic images. In the art of naturalism, artistic images are kept at an empirical level, "they crucially lack generalization, typification; they are rather sketches 'taken from life' than generalizations or types." 16 Thus, if the "social" core of a realistic personage is based on the principles of typification, the "biological" or "physiological"

13 Literaturoznavcha entsyklopediia [Literary Encyclopedia], vol. 2, edited by Yu. Kovaliv (Kyiv Akademiia, 2007), 306.

14 Zola, Le Roman expérimental, 15. (Quand on aura prouvé que le corps de l'homme est une machine, dont on pourra un jour démonter et remonter les rouages au gré de l'expérimentateur, il faudra bien passer aux actes passionnels et intellectuels de l'homme.) Translated by Belle M. Sherman.

Nalyvaiko, Iskusstvo, 149. (Unaturalistychnomu rozuminni seredovyshcha vse bilshe proiavliaietsia tendentsiia do zblyzhennia z "pryrodoiu" i, vidpovidno, bilshyi vidkhid vid "istorii.")

Here and subsequently, unless indicated otherwise, translations from Ukrainian are by Nataliia Venhrynovych.

16 Nalyvaiko, Iskusstvo, 151. (... yim krytychno ne vystachaie uzahalnennia, typizatsii, tse skorishe zamaliovky "z natury," nizh uzahalnennia, typy.) 
core of a naturalistic artistic image cannot be a generalized type; in it the individual prevails over the typified. We will attempt to trace the correlation of the social and biological in the structure of naturalistic personages, the artistic images of Germinie Lacerteux and Thérèse Raquin being their prototypes because of their authors' focus on the study of their temperaments.

The "Clinical Analysis of Love" depicted by the Goncourt brothers in their novel Germinie Lacerteux introduced into literature a new type of a personage, thus evoking its preconceived treatment by both critics and readers. Germinie is a maid, which in itself contradicts the traditional expectations of a "genteel" reading audience, being referentially ready to cognize a fictional picture of life being better than reality. Representatives of the "bottom of society" are introduced into a novel not for the first time, but it is the first time they dominate and play center stage. Proclaiming their intentions for rejuvenating contemporary art, the writers note:

Since Balzac, the novel has had nothing in common with what our fathers meant by the novel. The current novel is created according to documents narrated or taken from nature, as history is created according to written documents. ${ }^{17}$

In the novel Germinie Lacerteux, the role of the "human document" is played by the life story of the brothers' maidservant Rose Malingre, who takes the place of their mother. However, after the maid's death, her secret true nature, simulated honesty and fake modesty in the Goncourts' house as well as her dissolute nightlife are revealed. Nude sketches made during the last hours of Rose's life in the hospital, the observation of tuberculosis patients, the midwife Maria's stories about Rose's labour and her children's deaths define the main plot line of the work, that is the story of the maidservant's illness. All structural elements of character creation (image, behavior, manners, psychological state and mental condition, relationships with other characters, actions and deeds) have a common purpose, namely to reveal Germinie's biological principle, to trace her temperament as well as the effect of the environment, which has formed a perfect way of survival by any means, ignoring traditional moral laws, where every man is for himself, so it is the strongest and the slyest who survive. ${ }^{18}$ Formulating his theory of naturalism, Zola relied on his forerunners' experience, thus naturally acknowledging that "some pages of the novel can really shock the reader with

17 Edmond et Jules de Goncourt, Journal 2 (1891): 239, accessed May 4, 2017, https://fr.wikisource. org/wiki/Page: Goncourt_-_Journal,_t2,_1891. (Le roman depuis Balzac n'a plus rien de commun avec ce que nos pères entendaient par roman. Le roman actuel se fait avec des documents racontés, ou relevés d'après nature, comme l'histoire se fait avec des documents écrits.)

18 Nataliia Yatskiv, "Zasoby portretnoi kharakterystyky u romani brativ Gonkuriv Germinie Lacerteux [Means of Portrait Characteristics in the Goncourt Brothers' Germinie Lacerteux]," Sultanivski chytannia 3 (2014): 162-70. 
the truth revealed in them,"19 but was stubborn in defense of the Goncourt brothers against the accusations of literary critics who condemned the novel for its realism, for its excessive similarity to life, and a "purely medical point of view while speaking of hysteria." ${ }^{20}$ Investigating female characters in the Goncourt brothers' novels, Domenica De Falco concludes that hysteria is the most common female ailment of the nineteenth century. This disease became the research subject of so many literary works "that it can be defined, without risk of being mistaken, as an exclusively naturalistic illness." ${ }^{21}$ As a result of their passion for science, namely Bernard's and Brachet's medical treatises as well as Gallien's theory of temperaments, Flaubert, the Goncourts, and Zola seek to find an explanation for their personages' nervous disorders in physiological disbalances and in genetic and social law collisions, manifesting themselves in physiological and psychological disorders (neurosis, hysteria), thus proving their scientific hypothesis. Consequently, all Goncourt protagonists are sick, and the writers' literary works aim to confirm the thesis about the investigation of the disease, that is its manifestations at an early stage, its exacerbation provoked by adverse external factors, new age-related symptoms, and natural complications leading to death. The effect of religious doctrines on an unstable nervous nature can be observed in the images of Sister Philomena and Madame Gervaisais, the impact of a strict upbringing on an exceptionally warmhearted girl may be traced in the image of Renée Mauperin, and the pathological sensibility of a noblewoman - in Chérie. Domenica De Falco considers whether one may consider the Goncourts' morbid personages as extraordinary ones, in other words, being exceptional in the typical atmosphere of that time, or whether they are representative characters. She tends to think that the Goncourt brothers depict "a morbid century, which is nervous, lymphatic and melancholic at the same time." 22 Playing the part of historians of their time, they depart from depicting man in his social role, instead focusing on his inner life, and plunging into his complex psychology as well as numerous manifestations of his sensory and sensual spheres. Thus, the morbid "biological" principle of Goncourt personages is different from that of typified realistic characters, but at the same time it is representative of naturalistic doctrine, according to which personage depiction is governed by a scientific method.

While developing the concept of Thérèse Raquin, Zola is guided by physiological laws, namely, the effect of the environment on individuals, who are "sovereignly dominated by their nerves and their blood, deprived of a free will, led at each act of

\footnotetext{
19 Émile Zola, Mes haines, causeries littéraires et artistiques (Paris, 1893), 80.

20 Zola, Mes haines, causeries littéraires et artistiques, 8o.

21 Domenica De Falco, La Femme et les personnages féminins chez les Goncourt (Paris: Honoré Champion, 2012), 53. ([La maladie féminine la plus répandue au XIX siècle est, bien entendu, l'hystérie. Elle fait l'objet d'une telle exploitation romanesque] qu'on peut la définir, sans risque de se tromper, comme la maladie naturaliste par excellence.)

22 De Falco, La Femme et les personnages féminins chez les Goncourt, 66. (...c'est tout un siècle malade, à la fois nerveux, lymphatique et mélancolique.)
} 
their life by the fatalities of the flesh." ${ }^{23}$ The story of the protagonist does not fit into the paradigm of the laws of social life because her extraordinary innate features (barely controllable emotions, impetuosity, freedom-lovingness, leadership) are made to stand out against the background of the Raquins' dull monotonous commonplace existence. The suffocating hospital atmosphere at home and the aunt's daily routine drilling turn Thérèse into a soulless mechanism, a puppet used for household chores and a marionette for the realization of Mrs Raquin's and the sickly egocentric Camille's wishes. In the context of the experimental novel, Zola exposes his personages to conditions in which the hypothesis of the domination of heredity over social duties is evidenced by the emergence of Laurent, strong and sturdy, possessing a clearly expressed sexual appetite that awakens Thérèse's hot blood. Rationalistic modeling and prognostication are even intended to accurately calculate human passions. Moreover, this is made on account of the loftiest "positive" reasons:

We are experimental moralists showing by experiment in what way passion acts in a certain social condition. The day when we gain control of the mechanism of passion we can treat it and reduce it, or at least make it as inoffensive as possible. ${ }^{24}$

Zola's excessive enthusiasm for heredity and the physiological causation of human actions gave rise to the critics accusing him of their belief that the writer, "resting on various forms of mental illnesses, invalidating free will and reason, completely exposes man to the malignance of his temperament, in order to more clearly identify and more distinctly distinguish the innate features of the beast." ${ }^{25}$ Georges Lemaître, emphasizing the epic nature of Zola's novels, compares them with antique epic literature, nevertheless remarking:

While the great poets endowed their heroes with godlike features, Zola's personages are animalized. Epic gods embody natural forces,

23 Zola, Thérèse Raquin, 5. ([J'ai choisi des personnages] souverainement dominés par leurs nerfs et leur sang, dépourvus de libre arbitre, entraînés à chaque acte de leur vie par les fatalités de leur chair.) Translated by John Sterling.

Zola, Le Roman expérimental, 24. (Nous sommes des moralistes expérimentateurs, montrant par l'expérience de quelle façon se comporte une passion dans un milieu social. Le jour où nous tiendrons le mécanisme de cette passion, on pourra la traiter et la réduire, ou tout au moins la rendre la plus inoffencive possible.)

25 Georges Pellissier, Le Mouvement littéraire au XIXe siècle (Paris: Librairie Hachette, 1900), 347. (En donnant pour point de départ à toute son œuvre une névrose, Zola en indique d'emblée la signification. Il supprime par la même, autant qu'il est en son pouvoir, les forces libres de l'intelligence et de la volonté qui pourraient faire échec aux influences fatales du tempérament. Il s'annonçait dès le début pour ce qu'il devait être, non pas un peintre de l'homme, mais le peintre par excellence de ce que lui-même appelle la bête humaine.) 
Zola inserts into these forces, tamed by the human mechanism, a terrible life, the germ of a soul, and dark monstrous instincts. ${ }^{26}$

Thus, Les Rougon-Macquart may be called "a pessimistic epopee of human animality." 27 Literary critics claim that one of the achievements of naturalism is "the expansion of the thematic range of art, and above all, the shift of its center toward the depiction of the life of the common strata of society, that is those at the social bottom." 28 Subject matter democratization is closely connected with new types of naturalistic novel personages: workers, peasants, the unemployed, vagabonds, prostitutes, and beggars. Understanding their fate utilizing unbiased scientific methodology is impossible without revealing the entire "bottom" of their social life, namely the moral and physical handicaps caused by illness and unbearable living conditions.

We consequently have Zola's burning "vulgar" "naked truth" about hereditary diseases that receive a favorable environment in the society of the time: alcoholism (L’Assommoir), syphilis, erotomania (Nana), incest (La Curée), agitation, and hysteria (La Bête Humaine). The development of the natural sciences and sociological studies provide fruitful material for the naturalistic writers to in their literary works focus on those shortcomings, which lead to the deformation and degradation of society and affect the personages' psychology. Such "marginal" personages and plots attract the writers' attention not because of their uniqueness, but because they help expose public "ulcers": Nana in Zola's novel or Elisa in the Goncourt brothers' work are shown not only as prostitutes, but as members of a society that does not try to notice the problem as long as the prostitutes do not violate the external established order, and which refuses to treat them humanely, shaping their destinies as getting rid of something unnecessary and ugly.

Of course, the shocking scandalous nature of naturalistic discourse in the concept of its personages, representatives of the lower strata of the social "bottom," as well as in the shift of emphasis in the study of heredity and the environment could not evoke general acceptance and approval. But only by means of such methods was it possible to draw attention to painful problems, stir up discussion, and make people sit up and take notice of what they had been turning a blind eye to for centuries.

It is worth noting that such a model of a naturalistic personage put forward by the French writers was implemented in different ways in other national variants of the direction. According to scholars, both in English literature as in French, "the naturalistic

26 Jules Lemaitre, Les contemporains (Paris: Société française d'imprimerie et de librairie, 1886),

253. (... tandis que les vieux poètes tâchent à diviniser leurs figures, on a vu qu'il animalise les siennes. Les dieux dans l'épopée, ont été à l'origine les personnifications des forces naturelles: M. Zola prête à ces forces, librement déchaînées, une volonté obscure de monstres.)

27 Lemaitre, Les contemporains, 253. (... une épopée pessimiste de l'animalité humaine.)

28 Nalyvaiko, Iskusstvo, 139. (... rozshyrennia tematychnoho diapazonu khudozhnioi tvorchosti, a peredusim - zmishchennia tsentru na zobrazhennia zhyttia demokratychnykh verstv suspilstva, sotsialnykh nyziv.) 
movement originates in the depths of realistic art," ${ }^{29}$ and the elements of naturalism are easily found in

Dickens' narrative manner of the presentation of reality, in his addressing the topic of the accumulation of capital in certain hands and simultaneous impoverishment of the proletariat (Dombey and Son); in W. Thackeray's interest in the physiology of passion, his refusal of any idealization in his views on man and the environment surrounding him (Vanity Fair). ${ }^{30}$

English naturalism researcher Nataliia Kosylo believes that it is "the works of Dickens, Gaskell, Brontë that laid the foundation for subject matter having to do with the working class in European literature" 31 and made the first step in its elucidation in English literature of the late nineteenth - early twentieth centuries (namely in the works of G. Gissing, G. Moore, A. Morrison) in a naturalistic manner. However, in the works of the first group of writers, as in George Eliot's artistic works, there is no physiological determinism of the personages, and the novels of the latter appeal to the depiction of the social "bottom," they abound in physiological descriptions of instincts that determine the behavior of "animalized" personages a la Zola (A Mummer's Wife by Moore, The Nether World by Gissing).

German naturalism found a more complete expression in drama rather than in prose. G. Hauptmann, A. Holz, and J. Schlaf reflect on the problem of determinism in the "family drama." The power of hereditary biological instincts and the environment weighs heavily on Papa Hamlet, a personage of the eponymous story published by A. Holz and J. Schlaf under the pseudonym Bjarne P. Holmsen. Taking into account that in German literature naturalism developed simultaneously with realism, these writers afforded an impartial view of contemporary reality as well as calling for the depiction of life in all its diversity, without shying away from its ugly drastic sides.

29 Roman Holod, Naturalizm u tvorchosti Ivana Franka: do pytannia pro osoblyvosti tvorchoho metodu Kameniara [Naturalism in Ivan Franko's Creative Works: On the Question of His Creative Method] (Ivano-Frankivsk: Lileia-NV, 200o), 76. (... naturalistychna techiia zarodzhuietsia u nadrakh realistychnoho mystetstva.)

Holod, Naturalizm u tvorchosti Ivana Franka, 76. (...vzhe v opysovii maneri vykladu Ch. Dikensa, v yoho zvernenni do temy nahromadzhennia kapitalu v odnykh rukakh i odnochasno zubozhinnia proletariatu ("Dombi i syn”); u zatsikavlenni Tekereia fiziolohiieiu prystrastei, yoho vidmovi vid bud-yakoho idealizuvannia u pohliadakh na liudynu i seredovyshche, yake yii otochuie ("Yarmarok marnoslavstva").)

Nataliia Kosylo, "Kontsept naturalizmu v tvorakh na robitnychu tematyku Dzhordzha Gissinga ta Ivana Franka: heneza, typolohiia [The Concept of Naturalism in George Gissing's and Ivan Franko's Creative Works on the Labor Subject: Genesis, Typology]," Visnyk Prykarpatskoho universytetu. Filolohiia 23-24 (2009-2010): 283. (... tvory Ch. Dikensa, E. Gaskell, Sh. Bronte poklaly pochatok robitnychoi tematyky v yevropeiskii literaturi.) 
According to researchers, ${ }^{32}$ a popularizer and follower of naturalism in Ukrainian literature was Ivan Franko. In Matviishyn's opinion, in the French naturalists' works, I. Franko "saw, first of all, a new social vision of life, a democratic treatment of the lower strata of society, and a brave intervention in the general problems of contemporaneity." ${ }^{33}$ Searching for his own original manner for the veracious expression of the interrelationship between reality and man and nature, the Ukrainian writer creatively interpreted western European experience and on the basis of realistic and naturalistic art synthesized his own conception of "scientific realism," which may be considered an individual and national variant of naturalism. ${ }^{34}$ Naturalistic poetics are most often observed in Franko's early works: the Boryslav series abounds in detailed, factually accurate descriptions of everyday life, the external appearance of laborers, their working conditions, the very process of exhausting dangerous toil, torture scenes, naturalistic portraits of personages exhausted by work beyond their strength or crippled by torture (Petrii iDovbuschuky). A Zolaesque concept of the personage is manifested in the first version of Boa constrictor in the shaping of the image of Herman Goldkramer, in the depiction of his deprived and hungry childhood, in the portrayal of the dirt that constantly surrounds him, and in his behavior being determined by his inherited pathology:

She (Ryvka) passed her idiotic laziness and dullness on to her son, who also inherited his father's restlessness, a fact made apparent in his rare fits of rage and his constant, all-consuming need for destruction-destruction for the sake of destruction. ${ }^{35}$

Similar to the Goncourt brothers and Zola, Ivan Franko traces the symptoms of mental illness in Gotlieb's nervousness, in his constant irritation, and in his sadistic inclinations. Extending the traditions of the founders of naturalism, Franko includes the story of the life of the first Drohobych-Boryslav millionaire as the basis of the

32 Holod, Naturalizm u tvorchosti Ivana Franka; Nataliia Kosylo, Typolohiia anhliiskoho i ukrainskoho naturalizmu kintsia XIX_pochatku XX stolittia:problematyka, poetyka

[The Typology of English and Ukrainian Naturalism at the End of the 1gth-Beginning of the 2oth Centuries: Problems, Poetics] (Ternopil: Volodymyr Hnatiuk Ternopil National Pedagogical University, 2010); Matviishyn, Poetyka frantsuzkoho naturalizmu.

Matviishyn, Poetyka frantsuzkoho naturalizmu, 23o. (... vbachav peredusim nove sotsialne bachennia zhyttia, demokratychne stavlennia do suspilnykh nyziv, smilyve vtruchannia u zahalni problemy suchasnosti.)

Holod, Naturalizm u tvorchosti Ivana Franka, 87.

Ivan Franko, Zibrannia tvoriv u 50 tomakh [Collected Works in 50 Volumes], vol. 14.

(Kyiv: Naukova Dumka, 1978), 404. (Vona i synovi svoiemu peredala toto idiotychne linyvstvo i totu tupist, tilky shcho u Gotlieba do nei prymishalasia shche vittseva hariachka, vystupaiucha ridkymy vybukhamy liutosti i vichnoiu zhadoboiu nyshchennia, psuvannia ta trachennia vsioho bez dumky i bez tsili.) Translated by Fainna Solasko. 
plot of Boa constrictor, in which he traces the path of Herman Goldkramer's financial success through various kinds of fraud on the blood of ordinary oilmen, at the same time depicting the victim of his own destructive passion: "He was soon possessed by a blind lust for money, a terrible desire for it raged within his soul, wiping out every other feeling, forcing him to disregard every obstacle in his insatiable quest for gold." 36 Herman's morbid imagination is symbolically portrayed by means of the image of the boa, that

choked the gazelle's neck and back in a grip of steel, the unfortunate animal's head protruding from the brightly-coloured, glittering coils. Its large bulging eyes were full of agony and seemed liquidy with tears. The veins on its neck bulged, and one could practically see the last quivering movements of its head. The snake's eyes, on the other hand, burned with such demoniacal sinister glee, with such confidence in its own power, that a chill ran down your spine if you looked at it closely.37

Executed in the context of naturalistic poetics, the image of the gazelle's antemortem sufferings captivates the sick consciousness of the merchant and expresses his secret desire to possess wealth at any cost. With his friends, Herman even laughs at the careless victim, but while alone feels an indescribable fear of the snake's devilish eyes that paralyze the will and foretell a day of reckoning. Herman's pathological greed for enrichment is manifested with double force in his son Gotlieb. Thus, unlike the French writers, Franko analyzes signs of the disease not through the example of ordinary people, instead choosing the offspring of a wealthy merchant, implying the hopelessness of any further development of such a social system with its boundless rule of money, dissolution of morals, and loss of humanity.

Roman Holod, a researcher of naturalism in Ivan Franko's literary works draws attention to the sexopathological foundations of the behavior of some of the Ukrainian writer's personages, predetermining their expression by scientific tendencies of Franko's ideological and aesthetic conception. ${ }^{38}$ It is from this point of view, according

36 Franko, Zibrannia tvoriv u 50 tomakh, vol. 14, 398. (Povoli vyoho dushi rozhorialasia strashna, hariacha, slipa zhadoba hroshei, zahlushuvala vsiaki druhi chuttia, zakryvala pered yoho ochyma vsi zavady i manyla yoho tilky odnoiu metoiu — bahatstvom.) Translated by Fainna Solasko.

Franko, Zibrannia tvoriv u 5 o tomakh, vol. 14, 371. (... z vseiu syloiu styskaie svoimy veletenskymy skrudeliamy dobychu, shchoby podrukhotaty yii kosti. Vin obkrutyv yii shyiu i khrebet, a z-posered zakrutiv yoho sorokatoho blyskuchoho tila vydko holovu bidnoi zhertvy. Velyki ochi, vyhnani naverkh peredsmertnoiu mukoiu, blyshchat, nemov u sliozakh. Zhyly na shyi napruzheni,holova, nemov doochne bachysh, kydaietsia shche v poslidnikh sudorohakh. Zate ochi zmii blyskaiut takym zloradnym, demonichnym ohnem, takoiu pevnistiu svoiei syly, shcho mymovoli moroz probihaie po tili, koly dobre yomu prydyrytysia.) Translated by Fainna Solasko. 
to Holod, that the writer depicts the image of an erotomaniac, Mrs. Mikhonska, in the story Ne spytavshy brodu (Unknown Waters, 1886), as well as Mrs. Zheni's story about her husband's intimate physiological peculiarities in Velykyi shum (The Great Noise, 1907). Franko believes Mrs. Mikhonska's psychopathological deviations to be conditioned by heredity. Having the intention to write his memoirs, her father (old Remba) makes a compilation of "nearly all the pornography produced by the Polish gentry's rotten imagination." 39 By means of the artistic image of old Remba and his pseudoscientific writings, the author ridicules the aristocracy's instinctive desire to gain glory and recognition by any means. He makes fun of the noblemen's yearnings to justify their own meanness and depravity by scientific theories and ethnographic documents: "All of a sudden, the instinct of a collector and scientist has awakened in a man who has led a despicable life, but in fact he has the instinct to collect nothing but piggishness." 40 Thus, "a whole pyramid made of ugliness and obscenity" appears in a 1,ooo-page folio volume in an expensive leather binding. The volume becomes a "prayer book" for the old madman, who considers it his duty to read aloud selected pages to his guests with an educational and instructive aim, as the information written there is even more reliable and truthful than priests' sermons. The image of Remba resembles the image of the philosopher Sixte, the protagonist in Paul Bourget's novel Le Disciple (1889), who formulates the foundations of a new morality on the principles of scientific methods. For the sake of a more accurate study of moral phenomena, he offers to apply the experimental sciences. As biologists, physiologists, and medical practitioners allow the "vivisection of animals," there is no reason to ignore the "vivisection of the human soul," of course, in the name of a great scientific aim and on the basis of indisputable scientific data and methods. Both Mr. Remba's and the philosopher Sixte's striving for the acknowledgement of their writings as scientific researches and claims for affirmation of the "truth" lead to tragic consequences. In the story Unknown Waters, Mr. Remba's daughter, Mrs. Mikhonska, becomes an erotomaniac. Finding no satisfaction of her desires and seeing the object of her passion leaving the house, she dies of a stroke. The philosopher Sixte's faithful disciple Robert Greslou, who decides to put his teacher's theory of the "vivisection of the soul" into practice and to carry out an experiment on a young girl, makes notes of all his observations on the development of the love process for the sake of science. But at the end of the experiment, having put the girl up to suicide, he himself becomes a victim of her brother's revenge. In both stories, the pseudoscientists do not consider themselves involved in the resulting tragedies and do not realize their responsibility for affecting the lives of others with their own illusions.

Theories of the sexual background of psychological processes as well as theories of hereditary inclinations were very popular in world literature at the turn of the century,

Franko, Zibrannia tvoriv u 50 tomakh, vol. 18, 443. (...trokhy shcho ne vsei pornohrafii, yaku tilky vyprodukuvala pidhnyvaiucha na pni polska shliakhetska fantaziia). 
among them Charles Darwin's theory about "race," Claude Bernard's experimental medicine, Cesare Lombroso's concept of the biological nature of crime, and later on, Sigmund Freud's theory of psychoanalysis. A scientific foundation underlies the concept of Franko's pathological types, such as Father Telesnytsky, Gotlieb, and Prokip among others. A similar type is depicted by the writer on the pages of his novel Perekhresni stezhky (Fateful Crossroads, 190o) in the image of the sadist Stalskyi. His constitutional bias towards sadism had manifested itself as far back as his school years. Ye. Rafalovych recollects:

Stalskyi tortured the cat in multiform ways: he blindly beat it in a bag, hung it by the neck having split its tail at one end with a splinter, extirpated its claws, burned out its eyes, pierced it with an awl, stuffed its nose with crushed pepper and glass. ${ }^{41}$

As an adult Stalskyi turns into a despotic man who enjoys his wife's torture:

I simulate complete indifference, I pretend not to see her, but in reality, I not only see her, but I dutifully observe her. I'm a systematist ... I go about my business slowly, calmly, coolly, but she is none the better for it. ${ }^{42}$

Stalskyi's pathological inclination to enjoy his wife's torture is manifested in his constant search for new methods of sadism and in his gloating over her horror, "when an expression of wild fear and green fright appears on her face. She grows stiff and becomes numb, apparently she's afraid that I may stab or choke her to death." ${ }^{43}$ After torturing her he goes to bed and "while she is sobbing, he falls asleep so nicely and calmly as if falling asleep to the monotonous sound of rain falling in tin eavestroughs in autumn." 44

It is worth agreeing with the views of Ukrainian researchers Taras Pastukh and Roman Holod, formed on the basis of German psychologist's K. Leonhard's classification,

Franko, Zibrannia tvoriv u 50 tomakh, vol. 20, 179. (Stalskyi muchyv kota nairiz nishymy sposobamy: byv yoho v mishku naoslip, vishav za shyiu, pryshchemyvshy khvist rozkolenym z odnoho kintsia polinom, vyryvav pazury, vypikav ochi, kolov shylom, napykhav u nis tovchenoho pertsiu i skla.)

Franko, Zibrannia tvoriv u 50 tomakh, vol. 20, 211. (Ya udaiu povnu baiduzhist, udaiu pry nii, shcho ne bachu yii, ale na dili ya ne tilko bachu, ale navit pylno, observuiu yii. Ya systematyk ... ya robliu svoie dilo pomalu, spokiino, kholodno, ale yii vid sioho ne lehshe.) Franko, Zibrannia tvoriv u 50 tomakh, vol. 20, 214. (... na yii lytsi vystupaie vyraz dykoho strakhu, zelenoho pereliaku. Vona stoit, mov zaderevila, mabut boitsia, shcho ya kolys otak zarizhu abo zadushu yii.) 
in relation to the following pathological types in Franko's literary works: "an irritable and ostentatious individual (Gotlieb); a sexopathologic erotomaniac (Remba); an over irritable / overexcitable, psychiatrically, psychiatrically unstable (Baran); an ostentation stuck / ritualistic demonstrably-fixated type of a sadist (Stalskyi)." ${ }^{45}$ As to the latter, his instinctive inclination for violence, manifesting itself since childhood in the form of animal abuse, turns into a process of his wife's constant long-term torture and various role playing (the role of a man ignoring his wife, the role of a man deciding to reconcile with his wife, the role of a "democratic" man allowing his wife to commit adultery with a former lover, the role of a morally indignant man). The classification of pathological types in Franko's literary works shows that the writer sought to interpret his personages' behavior in accordance with the scientific theories of the time and to find answers to questions about human nature.

Examining the poetics of character creation in Franko's short fiction, Oleksandra Fedun emphasizes the fact that the personalities of Franko's personages are formed by the immediate influence of the environment, but "the environment surrounding the personage in his childhood, in its development, establishes evermore complex connections with the immediate social environment." 46 Under conditions of social antagonism and urbanization exacerbation, a personage loses his ability to communicate, he finds himself alone with difficult problems that lead to a split in his inner world. The researcher shows that Franko evolves from sociology to psychology, which manifests itself in the creation of socio-psychological types. It is worth agreeing with Fedun that the short fiction of the Ukrainian author abounds in socio-psychological types of personages representing collective generalized features of particular environment representatives, namely workers, peasants, prisoners, children, Jews, priests among others. Personage personality formation to a large extent depends on their activity, a specific situation, and the array of relations between the individual and others. In his short fiction, Ivan Franko cannot trace the whole life story of a hero and thus conditions his actions with heredity issues. The author focuses on one episode in life that helps to perceive all the complexity of a character's inner world. Physiological determinism gives way to social determinism in Franko's personages.

Thus, the naturalistic personage pattern proposed by the Goncourt brothers and Émile Zola is focused on the physiological determinism of human behavior and on its biological essence, manifesting itself in individualized images. The endeavor to find the psychological motivation for human actions in a complex socio-historical existence incites the French naturalists to excessive enthusiasm for heredity. That is why their

Holod, Naturalizm u tvorchosti Ivana Franka, 82. (zbudlyva i demonstratyvna osoba (Gotlieb), seksualno-patolohichna osoba erotomana (Remba), "zastriahlo-zbudlyvyi" psykhichno-khvoryi (Baran), "demostratyvno-zastriahlyi" typ sadysta (Stalskyi).)

46 Oleksandra Fedun, "Psykholohichno-sotsialnyi aspect u malii prozi Ivana Franka [The Psychological and Social Aspects of Ivan Franko's Short Prose]," Ukrainske literaturoznavstvo 26 (2006): 67. (seredovyshche, yake otochuie heroia v dytynstvi, v miru yoho rozvytku vstanovliuie chymraz uskladnenishi zviazky z naiblyzhchym sotsialnym otochenniam.) 
personages, having morbid "physiological" cores, differ from typified realistic images, but at the same time demonstrate the scientific approach characteristic of naturalistic doctrine. Having studied the theory of French naturalism, Franko artistically interprets it in his scholarly-theoretical and literary works. Considering the movement's founders' viewpoint, Franko offers his own opinion:

The novelist has become not only a psychologist but a sociologist as well, he must now be a naturalist, an industrialist, a doctor, a lawyer, a craftsman, and a farmer to understand, to delve deeply into and to reproduce altogether diverse society, find everywhere phenomena that are essential, distinguishing them from those that are less important. ${ }^{47}$

Objectivism, scientism, commitment to the truth of life, photographism, and documentalism, all based on positivist ideological philosophical theory, which form the basis of the ideological and aesthetic doctrine of naturalism, are transformed by Ivan Franko into his "scientific realism," bringing it closer to the French naturalists. At the same time he dissociates it from their narrative strategy of the author's refusal from evaluative interference in the text, as the Ukrainian writer is almost always interested in the dualism of the objective scientific method and awareness-raising progress. The distinction of Franko's personage creation lies in the writer placing his characters not in a physiological but in a sociological frame, not confining himself to the observation and description of his "experimental" heroes' behavior, but offering instead a positive program for the correction of the identified shortcomings and drawbacks. The pattern of the morbid and sick naturalistic personages of the Goncourts and Zola is also found in Franko's novels, but such personages are not protagonists (excepting Herman Goldkramer). They are deprived of a future and doomed to physical death, as their spiritual deformation is no longer curable.

\section{Bibliography}

Bourget, Paul. Le Disciple. Paris: Lemerre, 1889 .

De Falco, Domenica. La Femme et les personnages féminins chez les Goncourt. Paris: Honoré Champion, 2012.

Fedun, Oleksandra. "Psykholohichno-sotsialnyi aspect u malii prozi Ivana Franka [The Psychological and Social Aspects of Ivan Franko's Short Prose]." Ukrainske literaturoznavstvo 26 (2006): 64-70.

47 Franko, Zibrannia tvoriv u 50 tomakh, vol. 28, 181. (Romanist stav ne tilky psykholohom i sotsiolohom, vin musyt buty teper i pryrodoznavtsem, i promyslovtsem, i likarem, i yurystom, i remisnykom, i khliborobom, shchob zrozumity, zahlybytysia i vidtvoryty nadto dyferentsiiovane suspilstvo, vsiudy naity yavyshcha istotni i vidmezhwvaty yikh vid mensh vazhlyvykh.) 
Franko, Ivan. Zibrannia tvoriv u 50 tomakh [Collected Works in 50 Volumes]. Vol. 14. Kyiv: Naukova Dumka, 1978.

Franko, Ivan. Zibrannia tvoriv u 5 o tomakh [Collected Works in 50 Volumes]. Vol. 18. Kyiv: Naukova Dumka, 1978.

Franko, Ivan. Zibrannia tvoriv u 50 tomakh [Collected Works in 50 Volumes]. Vol. 20. Kyiv: Naukova Dumka, 1978.

Franko, Ivan. Zibrannia tvoriv u 50 tomakh [Collected Works in 50 Volumes]. Vol. 28. Kyiv: Naukova Dumka, 1978.

Goncourt, Edmond et Jules de. Germinie Lacerteux. La Bibliothèque électronique du Québec, Collection À tous les vents. https://beq.ebooksgratuits. com/vents/ Goncourt-Germinie. pdf.

Holod, Roman. Ivan Franko ta literaturni napriamy kintsia XIX — pochatku XX stolittia [Ivan Franko and Literary Movements of the Late 19th-Early 2oth Centuries]. Ivano-Frankivsk: Lileia-NV, 2005.

Holod, Roman. Naturalizm u tvorchosti Ivana Franka: do pytannia pro osoblyvosti tvorchoho metodu Kameniara [Naturalism in Ivan Franko's Creative Works: On the Question of His Creative Method]. Ivano-Frankivsk: Lileia-NV, 2000.

Kosylo, Nataliia. "Kontsept naturalizmu v tvorakh na robitnychu tematyku Dzhordzha Gissinga ta Ivana Franka: heneza, typolohiia [The Concept of Naturalism in George Gissing's and Ivan Franko's Creative Works on the Labor Subject: Genesis, Typology]." Visnyk Prykarpatskoho universytetu. Filolohiia 23-24 (2009-2010): $283-89$.

Kosylo, Nataliia. Typolohiia anhliiskoho i ukrainskoho naturalizmu kintsia XIXpochatkuXX stolittia:problematyka, poetyka [The Typology of English and Ukrainian Naturalism at the End of the 19th-Beginning of the 2oth Centuries: Problems, Poetics]. Ternopil: Volodymyr Hnatiuk Ternopil National Pedagogical University, 2010.

Lemaitre, Jules. Les contemporains. Paris: Société française d'imprimerie et de librairie, 1886.

Matviishyn, Volodymyr. "Poetyka frantsuzkoho naturalizmu u svitli literaturnokrytychnykh zasad Ivana Franka [French Naturalist Poetics in the Light of Ivan Franko's Literary and Critical Foundations]." Literatura. Chas. Postati, edited by Nataliia Yatskiv, 229-36. Ivano-Frankivsk: Vasyl Stefanyk Precarpathian National University, 2013.

Nalyvaiko, Dmytro. Iskusstvo: napravleniia, techeniia, stili [Art: Movements, Trends, Styles]. Kyiv: Mystetstvo, 1985.

Pastukh, Taras. Romany Ivana Franka [Ivan Franko's Novels]. Lviv, 1997.

Pellissier, Georges. Le Mouvement littéraire au XIXe siècle. Paris: Librairie Hachette, 1900. Venhrynovych, Nataliia. Fenomen naturalizmu Ivana Franka i amerykanska proza kintsia XIX_pochatku XX stolittia [The Phenomenon of Ivan Franko's Naturalism and American Prose of the Late 19th-Early 2oth Centuries]. Ivano-Frankivsk: Vydavets H. M. Kushnir, 2016. 
Yatskiv, Nataliia. "Zasoby portretnoi kharakterystyky u romani brativ Honkuriv Germinie Lacerteux [Means of Portrait Characteristics in the Goncourt Brothers' Germinie Lacerteux]." Sultanivski chytannia 3 (2014):162-70.

Zola, Émile. Le roman expérimental. Paris: G. Charpentier éditeur, 1881.

Zola, Émile. Les Rougon-Macquart. L'Assommoir. La Bibliothèque électronique du Québec, Collection À tous les vents. https://beq.ebooksgratuits.com/ventsxpdf/Zola-07.pdf.

Zola, Émile. "Mes haines, causeries littéraires et artistiques." G. Charpentier et E. Fasquelle, éditeurs (1893): 67-84.

Zola, Émile. Thérèse Raquin. La Bibliothèque électronique du Québec, Collection À tous les vents. https://beq.ebooksgratuits.com/vents/zola-raquin.pdf.

Nataliia Yatskiv holds a PhD in philology and is a professor and head of the French Philology Department at Vasyl Stefanyk Precarpathian National University. She is the author of over 80 articles as well as textbooks approved by the Ministry of Education and Science of Ukraine. Her scholarly interests include Ukrainian-French literary relations, typological similarities and differences in Ukrainian literature in the context of world cultural and historical development.

Nataliia Venhrynovych holds a $\mathrm{PhD}$ in philology and is an associate professor at the Linguistics Department of Ivano-Frankivsk National Medical University. She is the author and co-author of over 40 articles, a monograph, and textbooks approved by the Ministry of Health of Ukraine. Her academic interests include Ukrainian-American literary relations of the late 19th - early 2oth centuries, English medical terminology, and the methodology of teaching English at higher medical educational institutes. 